\title{
REVIEW
}

\section{Clinical review: Serious adverse events associated with the use of rituximab - a critical care perspective}

\author{
Pashtoon M Kasi', Hussein A Tawbi ${ }^{2}$, Chester V Oddis ${ }^{3}$ and Hrishikesh S Kulkarni*1
}

\begin{abstract}
The advent of biologic agents has provided a more specific and targeted approach to the treatment of various hematological malignancies and other autoimmune disorders. Such biologic agents have been relatively well tolerated with fewer adverse events reported as compared with many other chemotherapeutic agents. Rituximab is a monoclonal antibody to the B-cell marker CD20 and is a common biologic agent widely used for the treatment of B-cell lymphoma, lymphoproliferative disorders, and inflammatory conditions that are refractory to conventional treatment, including rheumatoid arthritis and some vasculitides. However, through randomized controlled trials and post-marketing surveillance, an increasing number of serious adverse events are being associated with the use of rituximab, often leading to or complicating an intensive care unit admission. The purpose of this review is to focus on the severe complications that are associated with the use of rituximab and that require critical care. Management and prevention strategies for the most common complications along with some examples of its uses within the critical care setting are also discussed.
\end{abstract}

\section{Introduction}

Yearly sales of rituximab in the US already exceed $\$ 2$ billion, attesting to its increasing US Food and Drug Administration (FDA)-approved and off-label use in multiple clinical settings such as B-cell lymphoma, lymphoproliferative disorders, and refractory inflammatory conditions, including rheumatoid arthritis (RA)

\footnotetext{
*Correspondence: kulkarnihs@upmc.edu

'Department of Medicine, University of Pittsburgh Medical Center, N713 UPMC Montefiore, 200 Lothrop Street, Pittsburgh, PA 15213, USA

Full list of author information is available at the end of the article
}

(Table 1) [1-5]. By mid-2011, 12,448 adverse events (AEs) associated with rituximab use were publicly reported to the FDA; of these, febrile neutropenia, pyrexia, pneumonia, and anemia were the most common [6]. Rituximab had been implicated as the suspect drug leading to death in 476 cases [6].

The cost of hospitalization due to adverse events associated with rituximab can be substantial, especially when they require an intensive care unit (ICU) admission. In a prospective multicenter study of adverse events associated with rituximab, patients with infusion reactions required significantly more staff time per infusion compared with those in whom no reactions occurred (164 versus 123 minutes) [7]. Grade 3 and 4 (severe, life-threatening) infusion reactions resulted in significantly higher infusion-associated human resource costs compared with when no infusion reactions occurred (median cost of $\$ 220$ versus \$120) [7]. In another study by the same authors, resuscitation carts needed to be used in $23 \%$ of patients (11 out of 47 ) with grade 3 or 4 infusion reactions. ICU admission occurred in two cases. The mean duration of hospitalization for a severe infusion reaction was 4 days [8]. Hence, the increasing frequency of use of rituximab in addition to its potentially serious adverse effects - either alone or in combination with other agents - warrants that intensivists, along with hematologists and rheumatologists, be familiar with the drug, especially when it is used in a critical care setting or when patients develop serious AEs (SAEs) requiring critical care management.

\section{Mechanism of action}

Rituximab is a chimeric monoclonal antibody directed against the CD20 B-cell antigen, a non-glycosylated phosphoprotein that is expressed on the surface of all mature B cells (Figure 1) [9]. It is not present on stem cells and is lost prior to B-cell differentiation into plasma cells. Hence, rituximab causes a selective, transient depletion of both the normal and malignant $\mathrm{CD} 20^{+} \mathrm{B}$-cell subpopulations and offers a more specific and targeted approach to B cell-driven disorders. In malignancies, 
Table 1. Common indications for rituximab therapy

\begin{tabular}{l} 
Disease conditions \\
\hline Chronic lymphocytic leukemia \\
CD20+ non-Hodgkin lymphoma (expressing the B-lymphocyte antigen CD20) \\
Rheumatoid arthritis \\
Anti-neutrophil cytoplasmic antibody (ANCA)-associated vasculitis \\
• Granulomatosis with polyangiitis (formerly Wegener's \\
$\quad$ granulomatosis) \\
$\quad$ Microscopic polyangiitis \\
$\quad$ Eosinophilic granulomatosis associated with polyangiitis (formerly \\
Chronic refractory graft-versus-host disease (unlabeled) \\
Refractory idiopathic thrombocytopenic purpura (unlabeled) \\
Hodgkin lymphoma (unlabeled) \\
Refractory pemphigus vulgaris (unlabeled) \\
Post-transplant lymphoproliferative disorder (unlabeled) \\
Waldenström macroglobulinemia (unlabeled) \\
Type I diabetes mellitus (unlabeled) \\
Multiple sclerosis (unlabeled) \\
Renal transplant (unlabeled)
\end{tabular}

rituximab also synergistically acts to sensitize B cells to other chemotherapeutic regimens $[3,9,10]$.

Figure 1 highlights the postulated mechanisms through which rituximab acts [9,11,12]: (1) antibody-dependent cell-mediated cytotoxicity: presumed predominant mechanism of action in vitro; (2) complement-dependent cytotoxicity; (3) direct effects of the drug: ligand binding leading to apoptosis or sensitization (or both) of the tumor to other chemotherapeutic agents; and (4) antibodydependent phagocytosis: through both Fc and complement receptors. These effects occur simultaneously and may complement one another, leading to a synergistic effect. This has led to multiple randomized clinical trials showing the beneficial effects of rituximab in many diseases, leading to its increasingly widespread use (Table 1) [13-15].

\section{Dosing}

Rituximab is administered as an intravenous infusion [9]. For treatment-naïve patients, it is started at a rate of $50 \mathrm{mg} /$ hour and is increased by $50 \mathrm{mg} /$ hour every 30 minutes to a maximum of $400 \mathrm{mg} /$ hour. Patients are premedicated with an analgesic/antipyretic (for example, acetaminophen), antihistaminic (for example, diphenhydramine), and a steroid (for example, methylprednisolone) 30 minutes prior to the infusion, mainly to minimize the severity of infusion reactions $[8,9,16]$. Often, a uricostatic agent (for example, allopurinol) and aggressive hydration are used prior to using rituximab for treating tumors with high cell burden, like lymphomas [9].

\section{Uses within the critical care setting} Rituximab as part of chemotherapeutic regimens

Rituximab is often administered in the ICU in patients who have lymphoproliferative disorders and who need combination chemotherapy but who have tumor lysis syndrome or are at high risk for this syndrome $[17,18]-$ for example, rituximab with cyclophosphamide, doxorubicin, vincristine, and prednisone (R-CHOP), rituximab with cyclophosphamide, doxorubicin, etoposide, and prednisolone (R-CHVP), rituximab with cyclophosphamide, vincristine, and prednisone (R-CVP), rituximab with fludarabine, cyclophosphamide, and mitoxantrone (R-FCM), and rituximab with mitoxantrone, chlorambucil, and prednisolone (R-MCP). Rituximab is often administered to patients in an ICU when they have a newly diagnosed malignancy with an extensive disease burden, multi-organ involvement, and/or disseminated intravascular coagulation [19].

\section{Refractory idiopathic thrombocytopenic purpura}

Idiopathic thrombocytopenic purpura (ITP) refractory to steroids and splenectomy can be challenging to treat. These patients may be transferred to an ICU for severe thrombocytopenia because of the risk of spontaneous intracranial bleeding. In patients with refractory ITP, response rates of up to $50 \%$ have been reported with rituximab [20].

\section{Post-transplant lymphoproliferative disorder}

Post-transplant lymphoproliferative disorder (PTLD) is being increasingly diagnosed ( $1 \%$ to $10 \%$ of transplant patients) in the setting of prolonged use of immunosuppressants. Rituximab in combination with other chemotherapeutic agents may be used in transplant ICUs, depending on disease severity. However, treatmentassociated mortality occurs in up to $11 \%$ of patients with PTLD $[21,22]$.

\section{Thrombotic thrombocytopenic purpura}

Severe thrombotic thrombocytopenic purpura (TTP) is often diagnosed in the ICU or necessitates an ICU admission on presentation. In a phase 2 trial of 40 patients with TTP, rituximab along with plasma exchange significantly decreased the duration of hospitalization and rate of relapse [23].

\section{Severe interstitial lung disease associated with connective tissue disease}

In a retrospective cohort study of patients with progressive interstitial lung disease (ILD) associated with connective tissue disease not responding to conventional immunosuppressive regimens, rituximab improved lung function in seven of eight patients [24]. Two of these patients were mechanically ventilated. Rituximab along 


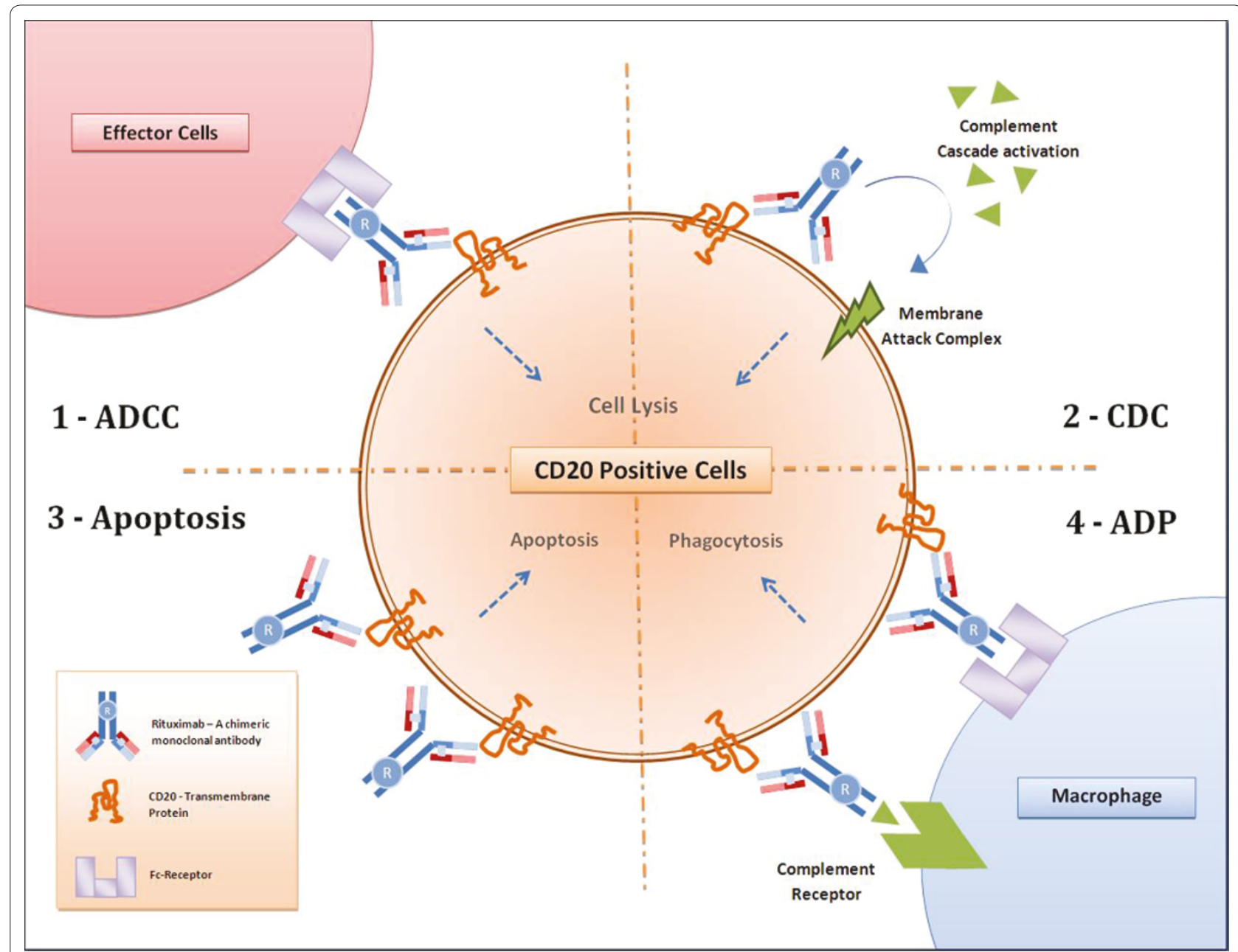

Figure 1. The proposed mechanisms of action for rituximab, a chimeric monoclonal antibody, against the CD 20 receptor. (1) Antibodydependent cell-mediated cytotoxicity (ADCC). Effector cells include natural killer cells and phagocytic cells such as monocytes and macrophages that express Fc receptors. (2) Complement-dependent cytotoxicity (CDC). (3) Direct effects of binding (induction of apoptosis and sensitization to other chemotherapeutic agents). (4) Antibody-dependent phagocytosis (ADP).

with cyclophosphamide has also been anecdotally used in the ICU in the treatment of severe ILD associated with antisynthetase syndrome [25].

\section{Pulmonary vasculitides}

Rituximab has been successfully used in patients who have diffuse alveolar hemorrhage related to systemic lupus erythematosus and who were either intolerant to cyclophosphamide or refractory to conventional immunosuppressive regimens $[26,27]$. It is also the first proven safe and effective alternative to cyclophosphamide to induce remission in patients with anti-neutrophil cytoplasmic antibody (ANCA)-associated vasculitis (Table 1) [28,29].

\section{Special populations}

Rituximab should be used with caution in older patients and in patients with cardiopulmonary disease [9]. Older patients (more than 55 years of age) have a higher rate of serious cardiopulmonary and infectious complications. Rituximab should also be avoided in any patient with severe infection [9]. It is a category $\mathrm{C}$ drug for pregnant women because animal studies have revealed deleterious effects on the fetus and controlled studies in women are lacking or unavailable [9]. Transient B-cell lymphocyte depletion has been reported in infants exposed to rituximab in utero [30]. Hence, it should be considered only if potential benefits outweigh risks to the fetus, such as in nonHodgkin lymphoma (NHL), refractory moderate-tosevere RA, and granulomatosis with polyangiitis or microscopic polyangiitis [9]. Although rituximab is secreted into the breast milk of lactating monkeys, there are insufficient data for or against its use during breastfeeding in humans [30]. 
Table 2. Common terminology Criteria for Adverse Events Version 4.0 (CTCAE) [31]

\begin{tabular}{ll}
\hline Grade of toxicity & Brief description \\
\hline Grade 1 & Mild; asymptomatic or mild symptoms; clinical or diagnostic observations only; intervention not indicated \\
Grade 2 & Moderate; minimal, local, or non-invasive intervention indicated; limiting age-appropriate instrumental $A D L^{\mathrm{a}}$ \\
Grade 3 & $\begin{array}{l}\text { Severe or medically significant but not immediately life-threatening; hospitalization or prolongation of hospitalization indicated; } \\
\text { disabling; limiting self-care } A D L^{\mathrm{b}}\end{array}$ \\
Grade 4 & Life-threatening consequences; urgent intervention indicated \\
Grade 5 & Death related to adverse event
\end{tabular}

${ }^{a}$ Instrumental ADL' refers to activities of daily living such as preparing meals, shopping for groceries or clothes, using the telephone, and managing money. ${ }^{b}$ Self-care $A D L$ 'refers to bathing, dressing and undressing, feeding oneself, using the toilet, taking medications, and not being bedridden. From the National Cancer Institute Common Terminology Criteria for Adverse Events v4.0 NCl, NIH, DHHS. May 29, 2009 NIH publication \#- 09-7473.

\section{Methods}

We searched PubMed using combinations of the following keywords: rituximab, biologics, adverse effects, side effects, toxicity, fatal, death, ICU, shock, cardiotoxicity, hepatotoxicity, neurotoxicity, respiratory failure, and renal failure. Randomized controlled trials, original studies (prospective or retrospective), systematic reviews, review articles, and case reports of patients treated with rituximab as well as relevant references from these papers were scrutinized and included in our review.

A SAE was defined as 'any untoward medical occurrence that at any dose results in death, is life-threatening, requires inpatient hospitalization or prolongation of existing hospitalization, results in persistent or significant disability/incapacity, is a congenital anomaly/birth defect, or requires intervention to prevent permanent impairment or damage' [31]. We included the National Cancer Institute (NCI) Common Toxicity Criteria Grading System to describe the severity of AEs or toxicities whenever they were mentioned in the original articles; higher grades denoted greater severity of toxicity [31] (Table 2). If the severity was not graded, we gave a description of the SAE. We used the same criteria system as proposed by the NCI to group AEs into 'system organ class' (SOC), which is identified by anatomical or physiological system, etiology, or purpose [32]. The adverse effects that were likely to be seen during (or that would be associated with) an ICU admission were included in the review. We focused on grade 3, 4, and 5 adverse reactions (Table 2).

\section{Results}

Thirty randomized controlled trials and one open-label extension study were included in the review, along with data from post-marketing surveillance and other case reports (see Supplementary File 1). We excluded two articles that were not in English [33,34]. The most common reactions (incidence of at least $25 \%$ ) in patients receiving rituximab monotherapy were infusion reactions and neutropenia [3,9]. Among these reactions, grade 3 and 4 toxicities were found in $57 \%$ of patients (203 out of 356) receiving rituximab [9]. Figure 2 outlines the major SAEs according to the SOCs of the NCI. Under each SOC, we first described reactions likely to occur soon after the administration of rituximab. We then briefly enumerated complications that were associated with more extended administration and that may require intensive care.

\section{Immunologic toxicity Infusion reactions}

Infusion reactions, ascribed to either anaphylaxis or allergic reactions, were the most common SAEs associated with rituximab in $80 \%$ to $90 \%$ of randomized controlled trials $[4,35,36]$. Many reactions developed within 24 hours of the first infusion, were dose-dependent, and were often more common in those who received rituximab versus those receiving the conventional chemotherapy regimen [4,14,37-39]. The frequency of the reactions decreased with subsequent cycles, and lifethreatening anaphylaxis was rare $[14,36,40]$. Notably, approximately $80 \%$ of all fatal reactions occurred with the first infusion [9].

There are also isolated case reports of severe or fatal SIRS (systemic inflammatory response syndrome)-like reactions (or both) developing within 24 hours of infusing rituximab $[25,41]$. These are likely a part of the spectrum of the 'cytokine release syndrome' that has been described after rituximab infusions in patients with high tumor-cell burden [42]. The reported clinical features included fevers, chills, rigors, nausea, dizziness, pruritus, urticaria/rash, angioedema, laryngeal edema, sneezing, throat irritation/tightness, cough, hoarseness, bronchospasm, pulmonary infiltrates, hypoxia, and acute respiratory insufficiency, with or without blood pressure changes or arrhythmias $[4,9]$. The severity of reactions was usually mild to moderate (grade 1 or 2); grade 3 to 4 reactions were rare and dose-dependent. For example, in a series of 465 patients treated for RA, acute infusion reactions increased from $17 \%$ in placebo-treated patients to $23 \%$ and $32 \%$ in those receiving two $500-\mathrm{mg}$ infusions and two 


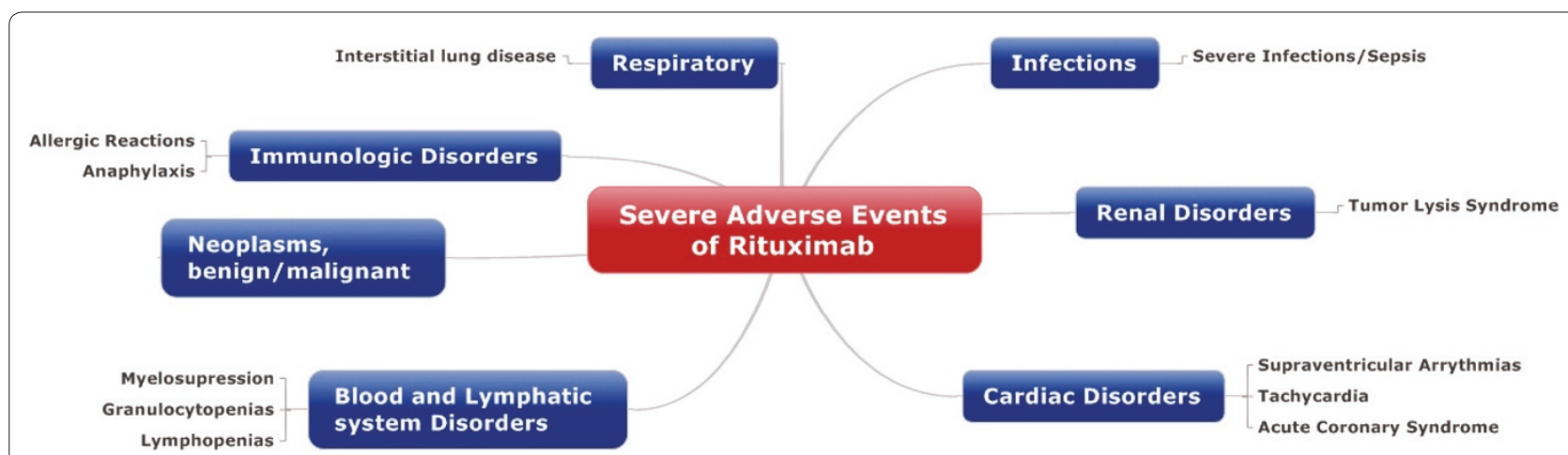

Figure 2. Major serious adverse events as categorized by the system organ class devised by the National Cancer Institute.

1,000-mg infusions of rituximab, respectively [36]. Interestingly, in studies of patients with AEs that are due to rituximab and that may lead to an ICU admission, $62 \%$ of patients (47 out of 76 ) receiving rituximab had a severe infusion reaction, but only two of these patients had a reaction that led to an ICU admission. This shows that many of these infusion reactions may potentially be manageable either under supervision in the outpatient setting or in monitored non-ICU hospital beds [43].

For mild infusion reactions, the rate of infusion was slowed or temporarily interrupted and was resumed at half the previous rate after symptoms abated. For moderate or severe infusion reactions, the infusion was held and subsequent infusions were not administered [9]. Patients were also given acetaminophen and intravenous antihistamine (for example, diphenhydramine) as well as epinephrine, bronchodilators, steroids, and oxygen if needed $[8,9,16]$.

The frequency of infusion reactions, which form the bulk of major SAEs due to rituximab administration, decreased in patients who were premedicated with intravenous glucocorticoids [36]. For example, in the series of 465 patients treated for RA, serious infusion reactions decreased from $32 \%$ in the group receiving two 500 -mg infusions of rituximab and $37 \%$ in the group receiving two 1,000-mg infusions of rituximab to $19 \%$ and $29 \%$, respectively, after premedication with intravenous glucocorticoids [36]. These findings were corroborated by a series of renal transplant patients who received induction therapy with rituximab prior to transplantation and who experienced minimal or no side effects and no significant infusion reactions [44]. These patients received $100 \mathrm{mg}$ of oral prednisolone as induction therapy for transplantation and this dose was reduced by $10 \mathrm{mg}$ per day to a daily dose of $20 \mathrm{mg}$, which was maintained for 1 month. Whether a similar protocol of premedication with glucocorticoids minimizes SAEs in immunologically mediated diseases treated with rituximab remains to be seen, but has been recommended [9].

\section{Blood and lymphatic system disorders}

Grade 3 and 4 cytopenias lasting approximately 2 weeks have been seen in $48 \%$ of patients who had NHL and who received rituximab monotherapy, lymphopenia being the most common [9]. However, cytopenia was more common in chemotherapy trials of regimens in which rituximab was combined with agents more frequently associated with myelosuppression $[39,45,46]$. For example, granulocytopenia (grades 3 and 4) occurred in $72 \%$ of R-CHOP-treated patients compared with $57 \%$ of CHOP-treated patients in 64 patients with lymphoplasmacytic lymphoma/Waldenström macroglobulinemia [45].

Whether these cytopenias have clinical implications is unproven $[45,47,48]$. In a study of 139 patients with mantle cell lymphoma, leukopenia (grades 3 and 4) occurred in $58 \%$ of patients receiving rituximab and a fludarabine-containing regimen (R-FCM) versus $41 \%$ in patients who received the fludarabine-containing regimen $(\mathrm{FCM})(P=0.02)$ [47]. This was mainly due to lymphopenia rather than neutropenia; the frequency and severity of the latter were similar in the two groups. The rate of infections or febrile reactions was no greater in the group of patients receiving rituximab [47]. Thus, although rituximab-augmented chemotherapeutic regimens may cause transient or sustained leukopenia or lymphopenia, the risk of developing serious infections or long-term outcomes is unclear. One reason for this discrepancy is that these studies are not powered to detect serious infections, as is evident by conflicting results $[38,47]$. Another plausible reason is that, as seen with other drugs, the degree of immunosuppression induced by different doses of a drug may not necessarily correlate with the predisposition to develop a serious infection [49]. Also, the interaction between the underlying disease state and the pharmacotoxicity of an immunosuppressant - either as a single agent or in combination with another drug - may influence this predisposition toward serious infections [38,50,51]. 


\section{Infections}

Although studies have shown an increased frequency of infectious complications with rituximab within 1 year after completion of treatment, most infections either resolved or were treated without any major sequelae. Among 356 patients with lymphoid malignancies treated with rituximab, 31\% developed bacterial infections, 10\% developed viral infections, and $1 \%$ developed fungal infections; in 6\%, the etiology was unknown [9]. In a trial of 620 patients with RA, the rate of serious infections was higher in the methotrexate (MTX)-rituximab group compared with the rate in the MTX-placebo group (5.2 versus 3.7 per 100 patient-years) [14]. Six of the serious infections in the MTX-rituximab group - gastroenteritis, pyelonephritis, cat bite infection, influenza, fever of unknown etiology, and de novo hepatitis B virus (HBV) resolved without sequelae, and one (gangrenous cellulitis) resulted in a toe amputation [14].

There is a dose-dependent increase in the frequency of infections in patients treated with rituximab for varying lengths of time [39]. Although older patients are at an increased risk of developing severe infectious complications, such infections are rarely fatal $[4,15,46,52]$. For example, in a study of 824 patients with diffuse large Bcell lymphoma, three in the R-CHOP group died of sepsis [52]. Other fatal infections after rituximab administration include pneumonia and colitis [9].

In a review of serious viral infections associated with rituximab use, 64 cases were identified [53]. The median time from rituximab treatment to the diagnosis of the viral infection was approximately 5 months. The most frequently experienced viral infections were HBV infection $(39.1 \%, \mathrm{n}=25)$, cytomegalovirus infection $(23.4 \%$, $\mathrm{n}=15)$, varicella-zoster virus $(9.4 \%, \mathrm{n}=6)$, and others $(28.1 \%, \mathrm{n}=18)$ [53]. Patients treated with rituximab carry a risk for HBV reactivation and hence should be screened for HBV prior to starting therapy [9]. This is based on a study from China in which, among 50 patients who had diffuse large B-cell lymphoma and who received rituximab, $60 \%$ had reactivation of the virus, $45 \%$ had severe hepatitis, and 25\% died [54]. HBV reactivation is an indication for discontinuing therapy [9]. Patients with severe HBV have had up to $52 \%$ reported mortality compared with $33 \%$ in the other patients. There is insufficient evidence either for or against the use of rituximab in patients with latent hepatitis $C$ virus infection [9].

\section{Renal disorders}

Urine output and trends in serum creatinine need to be closely monitored in patients receiving rituximab. Acute tumor lysis syndrome (ATLS) leading to acute kidney injury has been observed after rituximab monotherapy, especially in conditions with high tumor burden, like
NHL [9]. ATLS results from 'the rapid destruction of malignant cells, which abruptly release intracellular ions, proteins and metabolites into the extra-cellular space' [55]. In high concentrations, acutely released uric acid can crystallize in renal tubules, leading to renal insufficiency. Early signs of ATLS include hyperkalemia, hypocalcemia, hyperphosphatemia, or hyperuricemia. Prophylactic measures include intravenous hydration and antihyperuricemic therapy (allopurinol) prior to the infusion [9]. Alkalization of the urine is controversial [55]. In high-risk cases (for example, acute leukemia with a white blood cell count of greater than $100,000 / \mathrm{mm}^{3}$, Burkitt lymphoma, or renal insufficiency in the setting of intermittent-risk disease), a single dose of 0.1 - to $0.2-\mathrm{mg} / \mathrm{kg}$ recombinant urate oxidase (rasburicase), repeated if clinically necessary, can be used to reduce uric acid burden in patients at high risk for ATLS [56]. Management of ATLS is mainly supportive and includes close monitoring of electrolyte abnormalities described above, volume status, and renal function as well as dialysis if necessary [55]. Providers should closely monitor for renal dysfunction when rituximab is combined with cisplatin [9].

\section{Cardiac disorders}

Cardiac monitoring is necessary during and after rituximab infusions in all patients with a history of arrhythmias or angina [9]. In a study of 399 older patients with diffuse large B-cell lymphoma treated with either CHOP plus rituximab (R-CHOP) or CHOP alone, approximately $8 \%$ of patients in each group developed grade 3 or 4 cardiac AEs [57]. However, supraventricular arrhythmias and tachycardia were higher in the R-CHOP group versus CHOP alone. Similarly, a case of supraventricular tachycardia was reported in a study of patients with RA [13].

Myocardial infarctions have also been reported but are rare [35-37], as were severe hypertension and cardiac tamponade [14]. Rare cases of fatal heart failure have been reported after using rituximab (either as monotherapy or combination chemotherapy), independent of pre-existing heart disease [58-60]. New-onset cardiogenic shock developed in a 20-year-old female treated with rituximab for TTP refractory to plasma exchange [61]. Both acute respiratory failure and biventricular cardiogenic shock improved after rituximab was held and plasma exchange was continued. One case of fatal myocarditis was documented on autopsy in a study of 202 patients treated with rituximab for follicular lymphoma [60].

\section{Respiratory, thoracic, and mediastinal disorders}

In a 2011 review of 418 patients treated with rituximab monotherapy, 5.3\% developed adverse pulmonary reactions [23]. Approximately two thirds of the reactions were infectious, but nearly one quarter resulted in the 
development of ILD. ILD subsequently improved although only half of those patients had received intravenous steroids [23]. Hypoalbuminemia was identified as an independent risk factor for developing adverse pulmonary events.

Rare cases of status asthmaticus, bronchiolitis obliterans, hypersensitivity pneumonitis, and diffuse alveolar hemorrhage (fatal and non-fatal) have also been reported after using rituximab $[9,36,62-64]$. Bronchiolitis obliterans presenting as cough, dyspnea, and pulmonary nodules has been described in patients receiving rituximab [62]. Hypersensitivity pneumonitis presented as dyspnea, hypoxemia, eosinophilia, and pulmonary infiltrates [63]. Both bronchiolitis obliterans and hypersensitivity pneumonitis due to rituximab improved after stopping rituximab and administering steroids [62,63]. However, the response of diffuse alveolar hemorrhage to steroids was mixed [64].

\section{Neoplastic disorders}

In a 2012 review of trials of chemotherapeutic regimens containing rituximab, therapy-related neoplasms were identified in approximately $4.5 \%$ of patients (19 out of 426) within a follow-up period of 44 months [65]. Most cases presented as either acute myeloid leukemia or myelodysplastic syndromes and had often previously achieved at least partial (if not complete) remission. The median survival time was approximately 7 months after diagnosis of the therapy-related neoplasms; however, this was not specific to rituximab, since other agents were a part of the chemotherapeutic regimens. The presenting complaint and requirement for ICU admission in these cases are unknown; however, de novo acute myeloid leukemia may be diagnosed in the ICU when patients who have a history of cancer or who recently received chemotherapy present with acute respiratory failure, severe infection, bleeding, or renal dysfunction [66].

\section{Gastrointestinal disorders}

New-onset abdominal pain in patients receiving rituximab should prompt investigation for an acute abdomen. In post-marketing surveillance, 47 cases of bowel obstruction (nine deaths) and 37 cases of gastrointestinal perforation (four deaths) were reported by the end of 2006 among patients treated with rituximab, mainly for NHL [67]. In another series of 98 patients treated with combination chemotherapy containing rituximab, there were five severe gastrointestinal complications, including one leading to a death [39]. The average onset of symptoms is approximately 6 days (range of 1 to 77 days) after the first dose [9].

\section{Neurological disorders}

The development of new neurological signs in patients receiving rituximab should be evaluated with neuroimaging and a lumbar puncture if there is no other obvious etiology. Among 465 patients treated with rituximab for active RA refractory to MTX, one case each of a cerebrovascular infarction, convulsion, epilepsy, and serotonin syndrome were reported [36]. Extremely rare cases of fatal ischemic and hemorrhagic strokes have been reported [9]. Patients have also presented with JC virus reactivation, leading to progressive multifocal leukoencephalopathy [68]. These patients presented within 1 year of rituximab treatment for lymphoid malignancy or autoimmune disorders but had also received either immunosuppressive therapy or stem cell transplants. JC virus can be identified in the cerebrospinal fluid, and the diagnosis of progressive multifocal leukoencephalopathy is an indication to stop rituximab [9].

\section{Dermatologic disorders}

In a non-randomized, single-arm study of 356 patients treated for primary cutaneous B-cell lymphomas by using rituximab monotherapy, 37\% developed itching, rash, or urticaria [69]. Serious cutaneous side effects occurred in $2 \%$ of the study population. Rituximab infusions have been associated with paraneoplastic pemphigus, lichenoid dermatitis, vesiculobullous dermatitis, Stevens-Johnson syndrome, and toxic epidermal necrolysis, from immediately after the infusion until 3 months later [70]. Development of these severe reactions should prompt the discontinuation of rituximab [9].

\section{Conclusions}

The increasing use of biologics has allowed a more specific and targeted approach to the treatment of various hematological malignancies and other autoimmune disorders in which B-cell or humoral mechanisms appear to play a role in disease pathogenesis. Overall, these biologics appear to be well tolerated and lead to fewer AEs compared with other, more conventional therapies and chemotherapeutic regimens. However, their increasingly widespread and potentially prolonged use poses a new challenge and thus knowledge of SAEs related to rituximab is essential when dealing with patients suffering from such life-threatening complications.

At times, rituximab is administered in an ICU setting, and the intensivist may be the first to be alerted to the acute deterioration of a patient's clinical status. Rarely, the intensivist may be the accepting physician of a potentially fatal complication in a patient who recently received rituximab. Through our review of the major studies of rituximab and its use in various settings (both as a single agent and in combination therapy), we hope to increase awareness among intensivists regarding the SAEs associated with its use. Early identification and management may help reduce morbidity and mortality associated with these events. 


\section{Supplementary file}

Supplementary File 1 . This online file shows a list of studies included in the review along with rituximab dose used in the clinical trial and system-wide serious adverse events.

\section{Abbreviations \\ $A E$, adverse event; ATLS, acute tumor lysis syndrome; $C H O P$, \\ cyclophosphamide, doxorubicin, vincristine, and prednisone; FCM, \\ fludarabine, cyclophosphamide, and mitoxantrone; FDA, US Food and Drug Administration; HBV, hepatitis B virus; ICU, intensive care unit; ILD, interstitial lung disease; ITP, idiopathic thrombocytopenic purpura; MTX, methotrexate; NCI, National Cancer Institute; NHL, non-Hodgkin lymphoma; PTLD, post- transplant lymphoproliferative disorder; RA, rheumatoid arthritis; R-CHOP, rituximab with cyclophosphamide, doxorubicin, vincristine, and prednisone: R-FCM, rituximab with fludarabine, cyclophosphamide, and mitoxantrone; SAE, serious adverse event; SOC, system organ class; TTP, thrombotic thrombocytopenic purpura.}

\section{Competing interests}

The authors declare that they have no competing interests.

\section{Authors' contributions}

PMK contributed to the critical review of background literature and the original draft of the manuscript and helped revise the manuscript. HAT and CVO contributed to revising the text and ensured accuracy of the information contained and edited drafts of the manuscript. HSK contributed to the conception and design of the study, critical review of background literature, and drafting and revising of the manuscript prior to submission and helped revise the manuscript. All authors read and approved the final manuscript.

\section{Acknowledgments}

The authors thank Rodrigo Cartin-Ceba, of the Division of Pulmonary, Allergy and Critical Care Medicine, Mayo Clinic, Rochester, MN, USA, for his review of the manuscript and valuable suggestions. The authors appreciate the help of Abaseen Khan Afghan for his work on Figure 1.

\section{Author details}

'Department of Medicine, University of Pittsburgh Medical Center, N713 UPMC Montefiore, 200 Lothrop Street, Pittsburgh, PA 15213, USA. ${ }^{2}$ Division of Hematology/Oncology, Department of Medicine, University of Pittsburgh, 5150 Centre Avenue, Pittsburgh, PA 15232, USA. ${ }^{3}$ Division of Rheumatology and Clinical Immunology, Department of Medicine, University of Pittsburgh, Arthritis Institute, S705 BST, 3500 Terrace Street, Pittsburgh, PA 15261, USA.

\section{Published: 31 August 2012}

\section{References}

1. DiMasi JA, Grabowski HG: Economics of new oncology drug development. J Clin Oncol 2007, 25:209-216.

2. Aggarwal S: Targeted cancer therapies. Nat Rev Drug Discov 2010, 9:427-428.

3. Singh JA, Wells GA, Christensen R, Tanjong Ghogomu E, Maxwell L, Macdonald JK, Filippini G, Skoetz N, Francis D, Lopes LC, Guyatt GH, Schmitt J, La Mantia L, Weberschock T, Roos JF, Siebert H, Hershan S, Lunn MP, Tugwell P, Buchbinder R: Adverse effects of biologics: a network meta-analysis and Cochrane overview. Cochrane Database Syst Rev 2011, (2):CD008794.

4. Ghielmini M, Rufibach K, Salles G, Leoncini-Franscini L, Léger-Falandry C, Cogliatti S, Fey M, Martinelli G, Stahel R, Lohri A, Ketterer N, Wernli M, Cerny T, Schmitz SF: Single agent rituximab in patients with follicular or mantle cell lymphoma: clinical and biological factors that are predictive of response and event-free survival as well as the effect of rituximab on the immune system: a study of the Swiss Group for Clinical Cancer Research (SAKK). Ann Oncol 2005, 16:1675-1682.

5. Van Allen EM, Miyake T, Gunn N, Behler CM, Kohlwes J: Off-label use of rituximab in a multipayer insurance system. J Oncol Pract 2011, 7:76-79.

6. Rituximab Adverse Events and Side Effects Reported to the FDA (AERS) [http://www.drugcite.com/?q=rituximab].

7. Schwartzberg LS, Stepanski EJ, Walker MS, Mathias S, Houts AC, Fortner BV: Implications of IV monoclonal antibody infusion reaction for the patient, caregiver, and practice: results of a multicenter study. Support Care Cancer 2009, 17:91-98.

8. Schwartzberg LS, Stepanski EJ, Fortner BV, Houts AC: Retrospective chart review of severe infusion reactions with rituximab, cetuximab, and bevacizumab in community oncology practices: assessment of clinical consequences. Support Care Cancer 2008, 16:393-398.

9. Rituximab Package Insert (Biogen Idec Inc., and Genentech, Inc.) [http:// www.accessdata.fda.gov/drugsatfda_docs/label/2011/103705s5344lbl.pdf].

10. Taylor RP, Lindorfer MA: Drug insight: the mechanism of action of rituximab in autoimmune disease-the immune complex decoy hypothesis. Nat Clin Pract Rheumatol 2007, 3:86-95.

11. Maloney DG, Smith B, Rose A: Rituximab: mechanism of action and resistance. Semin Oncol 2002, 29 (1 Suppl 2):2-9.

12. Pescovitz MD: Rituximab, an anti-cd 20 monoclonal antibody: history and mechanism of action. Am J Transplant 2006, 6 (5 Pt 1):859-866.

13. Edwards JC, Szczepanski L, Szechinski J, Filipowicz-Sosnowska A, Emery P, Close DR, Stevens RM, Shaw T: Efficacy of B-cell-targeted therapy with rituximab in patients with rheumatoid arthritis. N Engl J Med 2004, 350:2572-2581.

14. Cohen SB, Emery P, Greenwald MW, Dougados M, Furie RA, Genovese MC, Keystone EC, Loveless JE, Burmester GR, Cravets MW, Hessey EW, Shaw T, Totoritis MC; REFLEX Trial Group: Rituximab for rheumatoid arthritis refractory to anti-tumor necrosis factor therapy: Results of a multicenter, randomized, double-blind, placebo-controlled, phase III trial evaluating primary efficacy and safety at twenty-four weeks. Arthritis Rheum 2006, 54:2793-2806.

15. Herold M, Haas A, Srock S, Neser S, Al-Ali KH, Neubauer A, Dölken G, Naumann R, Knauf W, Freund M, Rohrberg R, Höffken K, Franke A, Ittel T, Kettner E, Haak U, Mey U, Klinkenstein C, Assmann M, von Grünhagen U; East German Study Group Hematology and Oncology Study: Rituximab added to first-line mitoxantrone, chlorambucil, and prednisolone chemotherapy followed by interferon maintenance prolongs survival in patients with advanced follicular lymphoma: an East German Study Group Hematology and Oncology Study. J Clin Oncol 2007, 25:1986-1992.

16. Chung $\mathrm{CH}$ : Managing premedications and the risk for reactions to infusional monoclonal antibody therapy. Oncologist 2008, 13:725-732.

17. Benoit DD, Depuydt PO, Vandewoude KH, Offner FC, Boterberg T, De Cock CA, Noens LA, Janssens AM, Decruyenaere JM: Outcome in severely ill patients with hematological malignancies who received intravenous chemotherapy in the intensive care unit. Intensive Care Med 2006, 32:93-99.

18. Yang B, Lu XC, Yu RL, Chi XH, Zhang WY, Zhu HL, Yuan J, Zhao P: Diagnosis and treatment of rituximab-induced acute tumor lysis syndrome in patients with diffuse large B-cell lymphoma. Am J Med Sci 2012, 343:337-341.

19. Darmon M, Thiery G, Ciroldi M, de Miranda S, Galicier L, Raffoux E, Le Gall JR, Schlemmer B, Azoulay E: Intensive care in patients with newly diagnosed malignancies and a need for cancer chemotherapy. Critical Care Med 2005, 33:2488-2493.

20. Braendstrup P, Bjerrum OW, Nielsen OJ, Jensen BA, Clausen NT, Hansen PB, Andersen I, Schmidt K, Andersen TM, Peterslund NA, Birgens HS, Plesner T, Pedersen BB, Hasselbalch HC: Rituximab chimeric anti-CD20 monoclonal antibody treatment for adult refractory idiopathic thrombocytopenic purpura. Am J Hematol 2005, 78:275-280.

21. Trappe R, Oertel S, Leblond V, Mollee P, Sender M, Reinke P, Neuhaus R, Lehmkuhl H, Horst HA, Salles G, Morschhauser F, Jaccard A, Lamy T, Leithäuser M, Zimmermann H, Anagnostopoulos I, Raphael M, Riess H, Choquet S; German PTLD Study Group; European PTLD Network: Sequential treatment with rituximab followed by $\mathrm{CHOP}$ chemotherapy in adult B-cell posttransplant lymphoproliferative disorder (PTLD): the prospective international multicentre phase 2 PTLD-1 trial. Lancet Oncol 2012, 13:196-206.

22. Kulkarni HS, Kasi PM: Rituximab and cytokine release syndrome. Case Rep Oncol 2012, 5:134-140.

23. Kang HJ, Park JS, Kim DW, Lee J, Jeong YJ, Choi SM, Lee SM, Yang SC, Yoo CG, Kim YW, Han SK, Yim JJ: Adverse pulmonary reactions associated with the use of monoclonal antibodies in cancer patients. Respir Med 2012, 106:443-450.

24. Keir GJ, Maher TM, Hansell DM, Denton CP, Ong VH, Singh S, Wells AU, Renzoni EA: Severe interstitial lung disease in connective tissue disease: rituximab as rescue therapy. Eur Respir J 2012 Feb 9 [Epub ahead of print]

25. Kulkarni HS, Aggarwal R: Successful treatment of acute respiratory failure 
using rituximab and cyclophosphamide as a combination immunosuppressive regimen in a ventilator-dependent patient having antisynthetase syndrome. Am J Respir Crit Care Med 2011, 183:A5661.

26. Pottier V, Pierrot M, Subra JF, Mercat A, Kouatchet A, Parrot A, Augusto JF: Successful rituximab therapy in a lupus patient with diffuse alveolar haemorrhage. Lupus 2011, 20:656-659.

27. Pinto LF, Candia L, Garcia P, Marín Jl, Pachón I, Espinoza LR, Marquez J: Effective treatment of refractory pulmonary hemorrhage with monoclonal anti-CD20 antibody (rituximab). Respiration 2009, 78:106-109.

28. Stone JH, Merkel PA, Spiera R, Seo P, Langford CA, Hoffman GS, Kallenberg CG, St Clair EW, Turkiewicz A, Tchao NK, Webber L, Ding L, Sejismundo LP, Mieras K, Weitzenkamp D, Ikle D, Seyfert-Margolis V, Mueller M, Brunetta P, Allen NB, Fervenza FC, Geetha D, Keogh KA, Kissin EY, Monach PA, Peikert T, Stegeman C, Ytterberg SR, Specks U; RAVE-ITN Research Group: Rituximab versus cyclophosphamide for ANCA-associated vasculitis. N Engl J Med 2010, 363:221-232.

29. Cartin-Ceba R, Fervenza FC, Specks U: Treatment of antineutrophil cytoplasmic antibody-associated vasculitis with rituximab. Curr Opin Rheumato/ 2012, 24:15-23.

30. Ostensen M, Lockshin M, Doria A, Valesini G, Meroni P, Gordon C, Brucato A, Tincani A: Update on safety during pregnancy of biological agents and some immunosuppressive anti-rheumatic drugs. Rheumatology (Oxford) 2008, 47 Suppl 3:iii28-31.

31. CTCAE-FAQ - Vocab_Wiki [https://wiki.nci.nih.gov/display/VKC/Common+Te rminology+Criteria+for+Adverse+Events+FAQ]

32. Reporting serious problems to the FDA > what is a serious adverse event? [http://www.fda.gov/safety/medwatch/howtoreport/ucm053087.htm].

33. Forstpointner R, Hänel A, Repp R, Hermann S, Metzner B, Pott C, Hartmann F, Rothmann F, Böck HP, Wandt H, Unterhalt M, Hiddemann W: [Increased response rate with rituximab in relapsed and refractory follicular and mantle cell lymphomas - results of a prospective randomized study of the German Low-Grade Lymphoma Study Group]. Dtsch Med Wochenschr 2002, 127:2253-2258. In German.

34. Herold M, Ströhl J, Aßmann M, Eschenburg H, Franke A, Freund M, von Grünhagen U, Hahnfeld S, Hoffmann FA, Huhn D, Klinkenstein C, KnaufW, Pasold R, Hurtz H-J, Steglich J, Wolf H: [Acute toxicity of mitoxantrone, chlorambucil and prednisolone (MCP) versus MCP plus rituximab in lowgrade non-Hodgkin's lymphoma - Interim results of a phase III trial]. Onkologie 2000, 23:164-166. In German.

35. Keystone E, Fleischmann R, Emery P, Furst DE, van Vollenhoven R, Bathon J, Dougados M, Baldassare A, Ferraccioli G, Chubick A, Udell J, Cravets MW Agarwal S, Cooper S, Magrini F: Safety and efficacy of additional courses of rituximab in patients with active rheumatoid arthritis: an open-label extension analysis. Arthritis Rheum 2007, 56:3896-3908.

36. Emery P, Fleischmann R, Filipowicz-Sosnowska A, Schechtman J, Szczepansk L, Kavanaugh A, Racewicz AJ, van Vollenhoven RF, Li NF, Agarwal S, Hessey EW, Shaw TM; DANCER Study Group: The efficacy and safety of rituximab in patients with active rheumatoid arthritis despite methotrexate treatment: results of a phase IIB randomized, double-blind, placebo-controlled, doseranging trial. Arthritis Rheum 2006, 54:1390-1400.

37. Hauser SL, Waubant E, Arnold DL, Vollmer T, Antel J, Fox RJ, Bar-Or A, Panzara M, Sarkar N, Agarwal S, Langer-Gould A, Smith CH; HERMES Trial Group: B-cell depletion with rituximab in relapsing-remitting multiple sclerosis. N Engl J Med 2008, 358:676-688.

38. Pescovitz MD, Greenbaum CJ, Krause-Steinrauf H, Becker DJ, Gitelman SE, Goland R, Gottlieb PA, Marks JB, McGee PF, Moran AM, Raskin P, Rodriguez H, Schatz DA, Wherrett D, Wilson DM, Lachin JM, Skyler JS; Type 1 Diabetes TrialNet Anti-CD20 Study Group: Rituximab, B-lymphocyte depletion, and preservation of beta-cell function. N Engl J Med 2009, 361:2143-2152.

39. Aviles A, Nambo MJ, Neri N, Cleto S, Castaneda C, Huerta-Guzman J, Murillo E, Contreras M, Talavera A, Gonzalez M: Dose dense (CEOP-14) vs dose dense and rituximab (CEOP-14 +R) in high-risk diffuse large cell lymphoma. Med Oncol 2007, 24:85-89.

40. Coiffier B, Haioun C, Ketterer N, Engert A, Tilly H, Ma D, Johnson P, Lister A, Feuring-Buske M, Radford JA, Capdeville R, DiehI V, Reyes F: Rituximab (antiCD20 monoclonal antibody) for the treatment of patients with relapsing or refractory aggressive lymphoma: a multicenter phase II study. Blood 1998, 92:1927-1932

41. Seifert G, Reind I, Lobitz S, Seeger K, Henze G: Fatal course after administration of rituximab in a boy with relapsed all: a case report and review of literature. Haematologica 2006, 91 (6 Suppl):ECR23.
42. Winkler U, Jensen M, Manzke O, Schulz H, Diehl V, Engert A: Cytokine-release syndrome in patients with B-cell chronic lymphocytic leukemia and high lymphocyte counts after treatment with an anti-CD20 monoclonal antibody (rituximab, IDEC-C2B8). Blood 1999, 94:2217-2224.

43. Markert A, Thierry V, Kleber M, Behrens M, Engelhardt M: Chemotherapy safety and severe adverse events in cancer patients: strategies to efficiently avoid chemotherapy errors in in- and outpatient treatment. Int J Cancer 2009, 124:722-728.

44. Tyden G, Genberg H, Tollemar J, Ekberg H, Persson NH, Tufveson G, Wadstrom J, Gabel M, Mjornstedt L: A randomized, doubleblind, placebo-controlled, study of single-dose rituximab as induction in renal transplantation. Transplantation 2009, 87:1325-1329.

45. Buske C, Hoster E, Dreyling M, Eimermacher H, Wandt $H$, Metzner B, Fuchs R, Bittenbring J, Woermann B, Hohloch K, Hess G, Ludwig WD, Schimke J, Schmitz S, Kneba M, Reiser M, Graeven U, Klapper W, Unterhalt M, Hiddemann W; German Low-Grade Lymphoma Study Group: The addition of rituximab to front-line therapy with $\mathrm{CHOP}(\mathrm{R}-\mathrm{CHOP})$ results in a higher response rate and longer time to treatment failure in patients with lymphoplasmacytic lymphoma: results of a randomized trial of the German Low-Grade Lymphoma Study Group (GLSG). Leukemia 2009, 23:153-161.

46. Copelan E, PohIman B, Rybicki L, Kalaycio M, Sobecks R, Andresen S, Dean R, Koo A, Chan J, Sweetenham J, Bolwell B: A randomized trial of etoposide and G-CSF with or without rituximab for PBSC mobilization in B-cell nonHodgkin's lymphoma. Bone Marrow Transplant 2009, 43:101-105.

47. Eve HE, Linch D, Qian W, Ross M, Seymour JF, Smith P, Stevens L, Rule SA: Toxicity of fludarabine and cyclophosphamide with or without rituximab as initial therapy for patients with previously untreated mantle cell lymphoma: results of a randomised phase II study. Leuk Lymphoma 2009, 50:211-215.

48. Witzig TE, Gordon LI, Cabanillas F, Czuczman MS, Emmanouilides C, Joyce R, Pohlman BL, Bartlett NL, Wiseman GA, Padre N, Grillo-López AJ, Multani P, White CA: Randomized controlled trial of yttrium-90-labeled ibritumomab tiuxetan radioimmunotherapy versus rituximab immunotherapy for patients with relapsed or refractory low-grade, follicular, or transformed B-cell non-Hodgkin's lymphoma. J Clin Oncol 2002, 20:2453-2463.

49. Kremer JM, Bloom BJ, Breedveld FC, Coombs JH, Fletcher MP, Gruben D, Krishnaswami S, Burgos-Vargas R, Wilkinson B, Zerbini CA, Zwillich SH: The safety and efficacy of a JAK inhibitor in patients with active rheumatoid arthritis: Results of a double-blind, placebo-controlled phase lla trial of three dosage levels of CP-690,550 versus placebo. Arthritis Rheum 2009, 60:1895-1905

50. Bentdal OH, Froland SS, Larsen S: Cell-mediated immunity in anorexia nervosa augmented lymphocyte transformation response to concanavalin A and lack of increased risk of infection. Clin Nutr 1989, 8:253-258.

51. Singh G, Fries JF, Spitz P, Williams CA: Toxic effects of azathioprine in rheumatoid arthritis. A national post-marketing perspective. Arthritis Rheum 1989, 32:837-843.

52. Pfreundschuh $M$, Trümper $L$, Osterborg A, Pettengell R, Trneny M, Imrie K, Ma D, Gill D, Walewski J, Zinzani PL, Stahel R, Kvaloy S, Shpilberg O, Jaeger U, Hansen M, Lehtinen T, López-Guillermo A, Corrado C, Scheliga A, Milpied N, Mendila M, Rashford M, Kuhnt E, Loeffler M; MabThera International Trial Group: CHOP-like chemotherapy plus rituximab versus CHOP-like chemotherapy alone in young patients with good-prognosis diffuse large-B-cell lymphoma: a randomised controlled trial by the MabThera International Trial (MInT) Group. Lancet Oncol 2006, 7:379-391.

53. Aksoy S, Harputluoglu H, Kilickap S, Dede DS, Dizdar O, Altundag K, Barista I: Rituximab-related viral infections in lymphoma patients. Leuk Lymphoma 2007, 48:1307-1312.

54. Chen XQ, Peng JW, Lin GN, Li M, Xia ZJ: The effect of prophylactic lamivudine on hepatitis $B$ virus reactivation in $\mathrm{HBsAg}$-positive patients with diffuse large B-cell lymphoma undergoing prolonged rituximab therapy. Med Oncol 2011 May 10. [Epub ahead of print].

55. Darmon M, Ciroldi M, Thiery G, Schlemmer B, Azoulay E: Clinical review: specific aspects of acute renal failure in cancer patients. Crit Care 2006, $10: 211$.

56. Cairo MS, Coiffier B, Reiter A, Younes A; TLS Expert Panel: Recommendations for the evaluation of risk and prophylaxis of tumour lysis syndrome (TLS) in adults and children with malignant diseases: an expert TLS panel consensus. Br J Haematol 2010, 149:578-586. 
57. Coiffier B, Lepage E, Briere J, Herbrecht R, Tilly H, Bouabdallah R, Morel P, Van Den Neste E, Salles G, Gaulard P, Reyes F, Lederlin P, Gisselbrecht C: CHOP chemotherapy plus rituximab compared with $\mathrm{CHOP}$ alone in elderly patients with diffuse large-B-cell lymphoma. N Engl J Med 2002, 346:235-242.

58. Ghielmini M, Schmitz SF, Bürki K, Pichert G, Betticher DC, Stupp R, Wernli M, Lohri A, Schmitter D, Bertoni F, Cerny T: The effect of Rituximab on patients with follicular and mantle-cell lymphoma. Swiss Group for Clinical Cancer Research (SAKK). Ann Oncol 2000, 11 Suppl 1:123-126.

59. Lenz G, Dreyling M, Hoster E, Wörmann B, Dührsen U, Metzner B, Eimermacher H, Neubauer A, Wandt H, Steinhauer H, Martin S, Heidemann E, Aldaoud A, Parwaresch R, Hasford J, Unterhalt M, Hiddemann W: Immunochemotherapy with rituximab and cyclophosphamide, doxorubicin, vincristine, and prednisone significantly improves response and time to treatment failure, but not long-term outcome in patients with previously untreated mantle cell lymphoma: results of a prospective randomized trial of the German Low Grade Lymphoma Study Group (GLSG). J Clin Oncol 2005, 23:1984-1992.

60. Ghielmini M, Schmitz SF, Cogliatti SB, Pichert G, Hummerjohann J, Waltzer U, Fey MF, Betticher DC, Martinelli G, Peccatori F, Hess U, Zucca E, Stupp R, Kovacsovics T, Helg C, Lohri A, Bargetzi M, Vorobiof D, Cerny T: Prolonged treatment with rituximab in patients with follicular lymphoma significantly increases event-free survival and response duration compared with the standard weekly $x 4$ schedule. Blood 2004, 103:4416-4423

61. Millward PM, Bandarenko N, Chang PP, Stagg KF, Afenyi-Annan A, Hay SN, Brecher ME: Cardiogenic shock complicates successful treatment of refractory thrombotic thrombocytopenia purpura with rituximab. Transfusion 2005, 45:1481-1486.

62. Biehn SE, Kirk D, Rivera MP, Martinez AE, Khandani AH, Orlowski RZ: Bronchiolitis obliterans with organizing pneumonia after rituximab therapy for non-Hodgkin's lymphoma. Hematol Oncol 2006, 24:234-237.

63. Tonelli AR, Lottenberg R, Allan RW, Sriram PS: Rituximab-induced hypersensitivity pneumonitis. Respiration 2009, 78:225-229.

64. Heresi GA, Farver CF, Stoller JK: Interstitial pneumonitis and alveolar hemorrhage complicating use of rituximab: case report and review of the literature. Respiration 2008, 76:449-453.

65. Zhou Y, Tang G, Medeiros LJ, McDonnell TJ, Keating MJ, Wierda WG, Wang SA: Therapy-related myeloid neoplasms following fludarabine, cyclophosphamide, and rituximab (FCR) treatment in patients with chronic lymphocytic leukemia/small lymphocytic lymphoma. Mod Pathol 2012, 25:237-245.

66. Schellongowski P, Staudinger T, Kundi M, Laczika K, Locker GJ, Bojic A, Robak $O$, Fuhrmann V, Jäger U, Valent P, Sperr WR: Prognostic factors for intensive care unit admission, intensive care outcome, and post-intensive care survival in patients with de novo acute myeloid leukemia: a single center experience. Haematologica 2011, 96:231-237.

67. Cornejo A, Bohnenblust M, Harris C, Abrahamian GA: Intestinal perforation associated with rituximab therapy for post-transplant lymphoproliferative disorder after liver transplantation. Cancer Chemother Pharmacol 2009, 64:857-860.

68. Carson KR, Evens AM, Richey EA, Habermann TM, Focosi D, Seymour JF, Laubach J, Bawn SD, Gordon LI, Winter JN, Furman RR, Vose JM, Zelenetz AD, Mamtani R, Raisch DW, Dorshimer GW, Rosen ST, Muro K, Gottardi-Littell NR, Talley RL, Sartor O, Green D, Major EO, Bennett CL: Progressive multifocal leukoencephalopathy after rituximab therapy in HIV-negative patients: a report of 57 cases from the Research on Adverse Drug Events and Reports project. Blood 2009, 113:4834-4840

69. Gellrich S, Muche JM, Wilks A, Jasch KC, Voit C, Fischer T, Audring H, Sterry W: Systemic eight-cycle anti-CD20 monoclonal antibody (rituximab) therapy in primary cutaneous B-cell lymphomas-an applicational observation. $\mathrm{Br}$ J Dermatol 2005, 153:167-173.

70. Scheinfeld N: A review of rituximab in cutaneous medicine. Dermatol Online J 2006, 12:3.

\section{Supplementary references}

71. Common Terminology Criteria for Adverse Events v4.0 (CTCAE) [http:// ctep.cancer.gov/protocolDevelopment/electronic_applications/ctc.htm].

72. Aviles A, Nambo MJ, Castaneda C, Cleto S, Neri N, Murillo E, Huerta-Guzman J, Contreras M: Rituximab and escalated chemotherapy in elderly patients with aggressive diffuse large-cell lymphoma: a controlled clinical trial. Cancer Biother Radiopharm 2007, 22:194-199.

73. Freedman A, Neelapu SS, Nichols C, Robertson MJ, Djulbegovic B, Winter JN Bender JF, Gold DP, Ghalie RG, Stewart ME, Esquibel V, Hamlin P: Placebocontrolled phase III trial of patient-specific immunotherapy with mitumprotimut-T and granulocyte-macrophage colony-stimulating factor after rituximab in patients with follicular lymphoma. J Clin Oncol 2009 27:3036-3043.

74. Hainsworth JD, Litchy S, Shaffer DW, Lackey VL, Grimaldi M, Greco FA: Maximizing therapeutic benefit of rituximab: maintenance therapy versus re-treatment at progression in patients with indolent non-Hodgkin's lymphoma - a randomized phase II trial of the Minnie Pearl Cancer Research Network. J Clin Oncol 2005, 23:1088-1095.

75. Hiddemann W, Kneba M, Dreyling M, Schmitz N, Lengfelder E, Schmits R, Reiser M, Metzner B, Harder H, Hegewisch-Becker S, Fischer T, Kropff M, Reis $H E$, Freund M, Wörmann B, Fuchs R, Planker M, Schimke J, Eimermacher H, Trümper L, Aldaoud A, Parwaresch R, Unterhalt M: Frontline therapy with rituximab added to the combination of cyclophosphamide, doxorubicin, vincristine, and prednisone (CHOP) significantly improves the outcome for patients with advanced-stage follicular lymphoma compared with therapy with $\mathrm{CHOP}$ alone: results of a prospective randomized study of the German Low-Grade Lymphoma Study Group. Blood 2005 106:3725-3732.

76. Marcus R, Imrie K, Belch A, Cunningham D, Flores E, Catalano J, Solal-Celigny P, Offner F, Walewski J, Raposo J, Jack A, Smith P: CVP chemotherapy plus rituximab compared with CVP as first-line treatment for advanced follicular lymphoma. Blood 2005, 105:1417-1423.

77. Ribrag V, Gisselbrecht C, Haioun C, Salles G, Golfier JB, Ertault M, Ferme C, Briere J, Brice P, Mounier N: Efficacy and toxicity of 2 schedules of frontline rituximab plus cyclophosphamide, doxorubicin, vincristine, and prednisone plus bortezomib in patients with B-cell lymphoma: a randomized phase 2 trial from the French Adult Lymphoma Study Group (GELA). Cancer 2009, 115:4540-4546.

78. Salles G, Mounier N, de Guibert S, Morschhauser F, Doyen C, Rossi JF, Haioun C, Brice P, Mahé B, Bouabdallah R, Audhuy B, Ferme C, Dartigeas C, Feugier P, Sebban C, Xerri L, Foussard C: Rituximab combined with chemotherapy and interferon in follicular lymphoma patients: results of the GELAGOELAMS FL2000 study. Blood 2008, 112:4824-4831.

79. Hawker K, O'Connor P, Freedman MS, Calabresi PA, Antel J, Simon J, Hauser S, Waubant E, Vollmer T, Panitch H, Zhang J, Chin P, Smith CH; OLYMPUS trial group: Rituximab in patients with primary progressive multiple sclerosis: results of a randomized double-blind placebo-controlled multicenter trial. Ann Neurol 2009, 66:460-471.

doi:10.1186/cc11304

Cite this article as: Kasi PM, et al.: Clinical review: Serious adverse events associated with the use of rituximab - a critical care perspective. Critical Care 2012, 16:231. 